\section{War and exchange rate valuation}

\author{
Christopher E.S. Warburton
}

$\mathrm{T}$ his article investigates the extent to which the dominance of the United States dollar as an international currency has been contingent on American diplomacy rather than the prosecution of expensive wars. Four wars are of interest here, the Korean War (1950-1953), the Vietnam War (1964-1975), the Persian Gulf War (1990-1991), and the Iraq War (2003-present). The historical performance of the dollar in times of war and peace is examined. The Box-Jenkins forecasting algorithm is employed to make a short-term projection of the dollar coinciding with the Iraq war. The price of gold is used as a measure of the value of the U.S. dollar and investor confidence in the dollar during times of war and peace. The empirical evidence shows a short-term depreciation of the U.S. dollar coinciding with the Iraq War, a finding not atypical of the value of the dollar in times of war. Problems with the value of the U.S. dollar in times of war lead to the exploration of alternative forms of money, which if successful, can erode the continued dominance of the U.S. dollar as an international currency.

Historically, the basis of the dollar's dominance as an international currency has been the result of diplomacy before and after World War II and of geopolitical diplomatic arrangements in the 1970s and 1980s that enabled the dollar to be closely linked with gold and, subsequently, to become a numeraire for international currencies in international commodity markets. The dollar has been very influential in trading arrangements and commodity markets, one result of which prevented its collapse after the Vietnam War.

The empirical evidence shows a short-
term depreciation of the U.S. dollar
coinciding with the Iraq War, a finding
not atypical of the value of the dollar in
times of war.

In order to determine the sustainability of the dollar as a dominant international currency, this study on economic performance and currency valuation, unlike others, pointedly focuses on the historical value of the dollar in times of war and the reaction of economic agents to its value during such periods. To evaluate responses to the dollar's value in war time, Bank of England data on the monthly dollar price of gold for the period of January 2000 to March 2008 is employed, i.e., a time period mostly coincident with the ongoing Afghan and Iraq wars. The Box-Jenkins method is then used to forecast the dollar's direction.

The article is structured as follows. The first section contains a brief overview of the exchange rate literature. This is followed by an analysis of the emergence of the dollar as a dominant international currency. The penultimate section discusses the value of the dollar in the context of the relevant wars, followed by a discussion of the forecasting method. The final section presents the empirical results and conclusions.

The exchange rate literature

The exchange rate literature can be classified into three broad categories: exchange rate determination and forecasting, currency crashes (causes and consequences), and monetary nationalism or optimum currency areas. Apart from Krueger's early summary of the literature in terms of the current account, the capital account, or the interactions of both, research on exchange rate determination has focused on key economic variables such as interest rate, international trade (including capital flows), and the money supply or inflation. ${ }^{1}$ Some of the important fundamentals such as errors in money demand, foreign-exchange risk premiums, and the equilibrium real exchange rate are not observed by econometricians.

Exchange rate modeling has been controversial and inconclusive. For many years exchange rate forecasting models were judged on their performance against the random-walk model for forecasting exchange rates. This performance criterion was popularized by Meese and Rogoff who discovered that empirical exchange rate models of the 1970s that seemed to fit well within-sample did not have good out-ofsample fit, even though they use realized explanatory variables to predict exchange rates. $^{2}$

The work of Meese and Rogoff encouraged review of three models of analyses overshooting, monetary, and portfolio models - that were prevalent in the 1970s and early 1980s largely as a result of the work of Dornbusch, and Frenkel and Mussa. ${ }^{3}$ There appears to be some agreement in the literature that standard models that relate exchange rates to monetary variables like prices and interest rates perform poorly. ${ }^{4}$

In 1995 interest in empirical exchange rate model was revived, partly as a result of the finding by Mark that models could predict exchange rates over long horizons. ${ }^{5}$ However, some researchers are uncomfortable with long-term projections, although empirical evidence suggests that in the long-run exchanges rate can be explained by the variables predicted by the monetary model. It has been argued elsewhere that current account balances have an impact on the short-run dynamics of exchange rate movements in some cases, but that they do not affect the long-run dynamics of exchange rates. This evidence is consistent with the view that in a world of high capital mobility, exchange rates are a monetary phenomenon in the long-run. ${ }^{6}$

Although many researchers thought that standard models of exchange rates based on macroeconomic variables such as prices, interest rates, and output provide weak empirical results, Engel and others present evidence to the contrary while conceding that beating the random walk in forecasting is too stringent a criterion for accepting an exchange rate model. ${ }^{7}$ Comparatively recent studies highlight the role of expectations in determining exchange rate movements. As it stands, the literature shows a lack of consensus whether models are helpful in projecting exchange rate 
movements or that the models can be effectively evaluated. ${ }^{8}$

In forecasting the movement of the dollar during the planning and execution of the Afghan and Iraq wars, this study applies a univariate model for a variety of reasons. First, monetary variables - money supply, prices, and income — tend to exhibit endogeneity (interdependence); second, modeling expectations is beyond the scope of this work; third, the primary forecast motive of this article is to project the direction of the dollar during a period of war by relying on the data itself; and fourth, econometric theory shows that if theoretical speculations about economic structure are well-founded, then it can be shown that one manifestation of that structure generates an autoregressive moving average (ARMA) process for each of the endogenous variables in the structure. ${ }^{9}$

The literature on exchange rates has been diversified further as a result of the East Asian crises of the 1990s. Close scrutiny has been given to the causes and consequences of currency crises and crashes and were largely seen in terms of capital reversibility, destabilizing speculation, and moral hazard. ${ }^{10}$ As the literature evolved to its present form, war and currency preeminence has not formed a significant component of its content.

As a consequence of war, currency dominance is also contingent on the competition of successful optimum currency areas. ${ }^{11}$ In international monetary arrangements, optimum currency areas in competition with the dollar entail consequences for the dollar in times of peace and war.

The theory of the optimum currency area was developed by Mundell in the 1960s to show that fixed long-run exchange rates and common monetary policy could be beneficial for a region of nations. ${ }^{12}$ In the 1980 s he identified the possibilities of competition that the U.S. dollar could face. It was noted then that European Monetary Union (EMU) countries will eventually comprise a transaction domain that is considerably larger than the dollar area and that the euro will become an international currency on the same scale as the dollar. ${ }^{13}$ Anxiety over the value of the dollar and its war time depreciation makes gold and the euro more competitive and attractive as an alternative store of value.

Much more recent studies on the European currency area have focused on the evolution of the union and the conditions under which it might be beneficial to participate in an optimum currency area. ${ }^{14}$ There is a special interest in efficiency and openness in these recent studies. This article contributes to the literature in the area of war and questionable currency preeminence by maintaining that strong optimum currency areas, lack of dollar diplomacy, geopolitical anxiety, and the availability of competing forms of money challenge the dominance of the U.S. dollar as an international currency.

\section{Dollar diplomacy, Pax Americana, and the dominance of the U.S. dollar}

Three significant events promoted the U.S. dollar as an international currency by peaceful means between 1900 and 1975: first, dollar diplomacy; second, the Bretton Woods arrangement after the Second World War; and third, the successful arrangement with the Organization of Petroleum Exporting Countries (OPEC) to denominate the price of oil in international markets in U.S. dollars.

Dollar diplomacy (1900-1928) was a foreign policy phase designed to extend American economic interests abroad by peaceful means. Although American financial and commercial interests were extended to various areas of the world (including China) during this period, the policy was strategically developed to extend American influence in Latin America and the Caribbean after the Spanish American War of 1898.

The overriding objective of dollar diplomacy as it was articulated in 1911 by the then-Assistant Secretary of State, Francis Wilson, was to substitute dollars for bullets Notwithstanding its setbacks in Nicaragua and China under President Taft, dollar diplomacy created amazing opportunities for American commerce and national income that ultimately contributed to the stability of the dollar and its dominance in Latin America. In 1904, Panama dollarized fully and a substantial number of Latin American countries subsequently embraced de facto or full dollarization in the twentieth and twenty-first centuries. The problem of "original sin" — when a country cannot borrow in its own currency in international financial markets — hastened the pace of dollarization. ${ }^{15}$

American trade and investment with Latin America more than doubled between 1900 and 1910, and the U.S. State Department established a separate Latin American Bureau in 1909. American investment in Cuba rose to \$200 million in 1911, and it increased its economic power in the Dominican Republic. ${ }^{16}$

At the height of dollar diplomacy (1909-1913), before Woodrow Wilson repudiated it in theory although not necessarily in practice, the closing price of an ounce of gold on the New York Mercantile Exchange remained constant at \$20.67 an indicator of relative stability and confidence in the dollar for twelve years. The dollar price of an ounce of gold as quoted by the Exchange actually remained at this price from 1878 until the Great Depression of 1932.

Relative peace and booming commerce and industry placed the United States in an enviable position after World War II. As the Europeans decimated their infrastructure and ruined their economies during the World Wars, America emerged with a stronger economy, accumulated a balance of trade surplus, and extended the Marshall Plan to the Europeans. The World Wars created a monetary system in disarray, one that was characterized by a chaotic system of competitive devaluation and plummeting volume of trade. In the subsequent arrangement of the international monetary system (i.e., Bretton Woods), the dollar rose to prominence over the British pound and other currencies, and the new period of prosperity coincided with what became known as Pax Americana - the post-World War II period of American peace and economic and military superiority. Major conflicts among the great powers were avoided until the Korean War of the 1950s, a war which expedited the subsequent 
After the Bretton Woods fiasco, and the abandonment of the gold standard, the dollar's fortunes were restored in the international oil markets. The OPEC arrangement was propitious because it tied the dollar to the demand for a good with negligible price sensitivity; demand for oil and dollars became inextricably linked. It should be recalled, however, that the new financing of American debt with recycled petrodollars was largely the result of two wars (Korea and Vietnam) and expansionary monetary policy.

decline of the dollar.

The Bretton Woods system was a fixed exchange rate system in which nations determined the value of their currencies in relation to gold or the U.S. dollar equivalent of \$35 an ounce (called mint parity). As such, the system is sometimes referred to as the Gold Exchange Standard in which the dollar became a numeraire. The Bretton Woods system replaced this standard, and with the new system, the dominance of the British pound was dislodged by the dollar. Bretton Woods also brought the International Monetary Fund (IMF) into existence, the institution that oversees the smooth running of the international financial system. The new leadership role of the dollar created responsibilities for the U.S. government and its monetary authority.

The dominance of the dollar in the international monetary system meant that the United States was to maintain the price of gold at \$35 an ounce and be prepared to redeem dollars for gold at that price without restrictions. In effect, the United States was to guarantee the principle of convertibility. A challenging proposition, it meant fiscal and monetary discipline. As a result of two major wars (Korea and Vietnam) and unsustainable budget deficits, U.S. President Richard Nixon suspended convertibility in 1971 and the dollar was devalued by about 9 percent, from $\$ 35$ to $\$ 38$ per ounce of gold. ${ }^{17}$

The wars created loss of confidence in the dollar, symptomatic to a run on the Federal Reserve Bank system. In response, American businesses and policymakers resorted to strategic geopolitical diplomacy to sustain the dollar's dominance. For example, then-Secretary of State, Henry Kissinger, also famous for his shuttle diplomacy in the Middle East during the 1970s, was instrumental in establishing the United States-Saudi Arabian Joint Commission on Economic Cooperation. This was a forum for Saudi and American financial officials to discuss matters of common concern, and it provided a trajectory for the Saudi government to help U.S. companies increase their exports to Saudi Arabia, while the Saudis recycled petrodollars into long-term U.S. securities to finance U.S. debt. This economic cooperation soon included military protection for Persian Gulf states after the Soviet invasion of Afghanistan in $1979 .^{18}$

As the specter of geopolitical instability loomed over the Middle East, the Gulf Cooperation Council (GCC) of Saudi Arabia, Bahrain, Kuwait, Oman, Qatar, and the
United Arab Emirates was formed in 1981 to resist outside intervention in the Gulf and to promote regional economic integration. Under the leadership of Saudi Arabia, the GCC supported oil pricing in U.S. dollars, purchased U.S. debt securities, and accumulated U.S. dollars as foreign reserves. After the Bretton Woods fiasco, the dollar's fortunes were restored in international oil markets. The OPEC arrangement was propitious because it tied the dollar to the demand for a good with negligible price elasticity of demand; demand for oil and dollars became inextricably linked. It should be recalled, however, that the new financing of American debt was largely the result of two wars and expansionary monetary policy.

\section{War and the decline of the U.S. dollar}

There are substantive reasons why war diminishes the value of a currency. To prosecute wars, particularly over extended periods of time, nations lose foreign reserves and borrow or print money. For example, at the end of World War I Germany experienced hyperinflation mainly because it printed money to meet its reparation obligations. The price of a daily newspaper increased from 0.30 marks in 1921 to 70 million marks on 17 November 1923. ${ }^{19}$ After the Korean and Vietnam Wars, the United States lost a tremendous amount of gold reserves, which made it unrealistic to defend the dollar-gold exchange rate. Inability to maintain convertibility ultimately resulted in a devaluation of the dollar in the 1970s. The road to devaluation actually started in Korea in the 1950s. The Congressional Research Service (CRS) estimates the cost of the Korean War to have been $\$ 295$ billion (in 2007 dollars). ${ }^{20}$

Although the price of gold was held steady at \$35 per ounce because of the fixed exchange rate regime, it was exceedingly costly to maintain the mint parity or defend the dollar at that rate. The U.S. capital account (the sum of all long-run, private economic transactions by U.S. residents with other nations for a given time period) was in deficit in almost every year since 1950. From \$1billion per year between 1950 and 1957, it rose to \$3 billion per year from 1958 to 1970, and the U.S. financed its deficits from 1950 to 1970 with a \$13 billion loss of its gold reserves, equivalent to a decline in gold reserves of about 54 percent. ${ }^{21}$ For the duration of the Korean War, the price of gold fluctuated between \$35.5 and \$40.25 on the New York Mercantile Exchange.

The Vietnam War was twice as costly as the Korean War ( $\$ 670$ billion, in FY2007 dollars), ${ }^{22}$ and by 1968 the signs of pending inconvertibility were already evident. The surplus in the current account (the account which records transactions in goods, services, remittances, and income) deteriorated from \$8.5 billion in 1964 to \$4.8 billion in 1967. This coincided with the rapid expansion of U.S. military commitments in Southeast Asia and U.S. government imposed capital controls that restricted foreign investment by U.S. residents and reduced asset earnings abroad. ${ }^{23}$

The resulting outflow of dollars and gold increased destabilizing speculation and doubts about the ability of the United States to sustain convertibility. On 8 August 
1971 newspapers reported that the French were about to present \$191 million of reserves to the United States in exchange for gold to make loan repayment to the IMF. ${ }^{24}$ Speculation against the dollar intensified and gold flowed out of the country on a daily basis. On 15 August 1971 President Nixon made it known that the United States was no longer committed to exchange dollars for gold; he in effect suspended convertibility. The Smithsonian Agreement of December 1971 was an attempt to remodel the beleaguered international monetary system of the late 1960s and early 1970s, and it formalized the devaluation of the dollar by 9 percent.

Beyond Vietnam, the United States has been involved in two major wars, the Persian Gulf War of 1990-1991, which can be classified as a war of collective selfdefense in international law, and the ongoing Afghan and Iraq wars which started in 2001 and 2003, respectively. The Gulf War showed no detrimental impact on the U.S. currency, although it had of course economic and human costs. Data from the Bank of England show that the annual average price per ounce of gold for 1990 and 1991 was \$383.57 and \$362.10, respectively. In fact, gold depreciated against the dollar. The reason for this is that the United States did not have to print or borrow a significant amount of money to finance the cost of that brief war. The CRS indicates that the Gulf War cost \$94 billion (in 2007 dollars), of which the United States paid only $\$ 7$ billion. The rest of the money was paid by Saudi Arabia, Kuwait, and other countries. ${ }^{25}$ Unlike the Gulf War or earlier wars, financing the Iraq War has been a very expensive endeavor, with consequences for the value of the dollar. As of this writing, it is estimated that the cost of the war, excluding Afghanistan, is likely to reach $\$ 2.7$ trillion. $^{26}$

Salient lessons show that the cost of war is realistically inestimable. Much of the financial outcomes of wars depend on tactical strategies of belligerents (e.g., guerilla versus conventional warfare), post-war welfare remediation, and contingent economic shocks. Escalating oil prices and U.S. budget deficits resulted in stagflation in the 1970s, and of a milder form of it in 2008, partly because war-time planning has not generally considered the prospects of economic shocks adequately - for example, inflation, unemployment, or mortgage crises. For all the wars under consideration there has been a corresponding downturn in economic activity: July 1953 through May 1954, December 1969 through November 1970, July 1990 through March 1991, and arguably October 2007 to the time of writing.

\section{The Box-Jenkins method}

The forecasting method employed in this article provides a projection of the dollar's value in terms of gold during the Iraq War. It thus assesses the sustainability of the dollar as a dominant international currency. The dollar price per ounce of gold from January 2000 to March 2008 was obtained from the Bank of England, providing a total of ninety-nine observations.

Gold is a good measure of the value of the dollar because it is an alternative form of money that is un i vers a ll y acceptable, and it is generally used to hedge against the adverse effects of inflation or the depreciating value of a currency. It c a p t u r e s s peculative behavior and it is also a good numeraire to calculate crossexchange rates.

The Box-Jenkins (BJ) method is the preferred short-term forecasting tool used here. It enables one to evaluate the future direction of the dollar through stationarity and avoids the endogeneity problem associated with monetary exchange rate models. ${ }^{27}$ There are four important procedures to implementing the BJ algorithm. First, a visual analysis of the data to determine if there is a deterministic or seasonal trend; second, ensuring stationarity; third, diagnostic testing; and fourth, forecasting.

A visual representation of the dollar per ounce of gold exchange rate is provided in Figure 1. The illustration shows an upward deterministic trend, suggesting dollar depreciation (more dollars per ounce of gold) for the period under consideration. To speculate on the future of this trend it is tempting to mentally extend the curve upwards. But this is misleading unless knowledge of the statistical or random (stochastic) mechanism responsible for the trend is available (the data generating process, or DGP). To obtain knowledge of the DGP, it is essential to difference the data to remove the trend and make the series stationary. To achieve stationarity, we difference the log of the exchange rate to eliminate larger variances over time (heteroskedasticity). This also permits analysis of dollar depreciation in terms of percentage changes.

Figure 2 provides visual evidence that the deterministic trend shown in Figure 1 has been removed to obtain a constant mean of zero and unit variance. This second requirement of the $\mathrm{BJ}$ algorithm must be evaluated to ascertain successful stationarity because of the potential problem of underdifferencing or overdifferencing the data. Statistically, stationarity is ascertained by diagnostic testing or visual analysis of the autocorrelation (AC) and partial autocorrelation functions (PACF), the correlogram and the Q-statistic. ${ }^{28}$ 


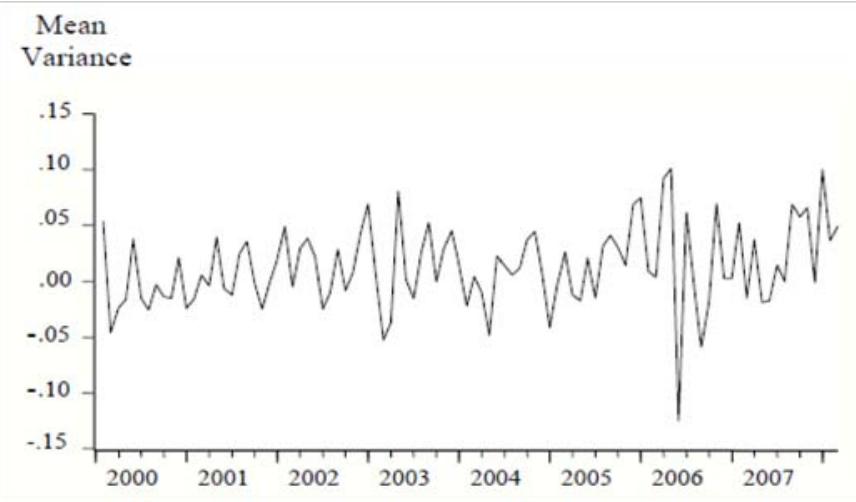

Figure 2: Mean and variance of the differenced/stationary gold/dollar series
Information

f r o m t h e diagnostic test is used to model the data generating process to make a r e a s o n a b l e projection (in this case, a static forecast) of the direction of the dollar's value in terms of the price of gold. The correlogram is a guide which indicates when autoregressive (AR) or moving average (MA) terms must be added or reduced, depending on the significance of the lags. The PACF suggests the required number of AR-terms because it acts like a partial difference, while the ACF suggests the required number of MA-terms to dampen the amount of unnecessary differencing.

After differencing the data and evaluating the correlogram and the Q-statistics, 7.44 and 12.27 at lags three and four, respectively, the corresponding AC-terms are found to be significant with p-values of 0.059 and 0.015 . The following forecasting model is specified:

(1) $r_{t}=\mu+\theta e_{t}+\theta e_{t-3}+\theta e_{t-4}$

where $r_{t}$, is the gold-U.S. dollar exchange rate at the end of March 2008, $\mu$ captures the average percentage monthly depreciation of the dollar, $\theta$ is the parameter of random shocks to be estimated, and $e$ refers to the random shocks associated with the exchange rate in war time. Shocks in the past three and four months prove to be very significant. These coincide with the fuel and mortgage crises. In ARIMA notation, the model can be expressed as $(0,1,4)$ which means, first, a zero autoregressive term, second, that the data is differenced once, and third, that the model is a moving average of the fourth order. The probable autoregressive terms are not found to be significant. The expression

(2) $\quad \theta e_{t}=r_{t}-\mu-\theta e_{t-3}-\theta e_{t-4}$

reflects the continuing assessment of past information on current decisions and its solution is normally referred to as the invertibility condition. ${ }^{29}$ An ARIMA model generates a solution for analysis if it is considered to be stable or invertible; otherwise
Table 1: Gold-U.S. dollar exchange rate January 2000-March 2008, Ordinary Least Squares Estimates (t-stat in parenthesis)*

\begin{tabular}{llll} 
Diagnostics & Value & Variables & Coefficient \\
Akaike criterion & -3.83 & Mean & $0.012(2.41)$ \\
Bias proportion & 0.002 & MA(3) & $0.23(2.43)$ \\
Variance proportion & 0.04 & MA(4) & $0.28(2.87)$ \\
Covariance proportion & 0.96 & \multicolumn{2}{c}{$\ldots$} \\
Inverted MA roots & $0.52+62 \mathrm{i}$ & $\ldots$ & $\ldots$ \\
& $0.52-62 \mathrm{i}$ & $\ldots$ & $\ldots$ \\
& $-0.52-0.40 \mathrm{i}$ & $\ldots$ & $\ldots$ \\
& $-0.52+0.40 \mathrm{i}$ & $\ldots$ & $\ldots$
\end{tabular}

it becomes explosive and unreliable.

\section{Empirical findings}

The overall results of the model and diagnostics are provided in Table 1 . They indicate that for the period under consideration, the value of the dollar, measured in terms of an ounce of gold, depreciated at a monthly average rate of 1.2 percent during the Iraq War. The moving average coefficients $(0.23$ and 0.28$)$ are significant at the 95 percent level of confidence and the null hypotheses that they are zero are rejected.

The Akaike information criterion, or AIC, of -3.83 is used to ascertain the required number of regressors (parsimony) and the performance of competing models. It penalizes for excessive regressors, and smaller values are generally preferred.

The bias, variance, and covariance proportions are used to evaluate the forecasting model because the root mean square error is sensitive to the units in which the relevant variable (i.e., the exchange rate) is estimated. The bias proportion of 0.002 indicates how far the mean of the forecast is from the mean of the actual series, the variance proportion of 0.04 indicates how far the variation of the forecast is from the variation of the actual series, and the covariance proportion of 0.96 is a measure of the remaining unsystematic forecasting errors. The forecast results shows that the bias and variance proportions are very low. These conditions are preferred for a better fit. The inverted MA roots show that the model is stable (can be solved) and not explosive.

The forecast of the dollar value is provided in Figure 3. The static forecast shows short-term depreciation of the dollar (more dollars per ounce of gold) with the commencement of the Afghan and then Iraq wars. The general trend of this 


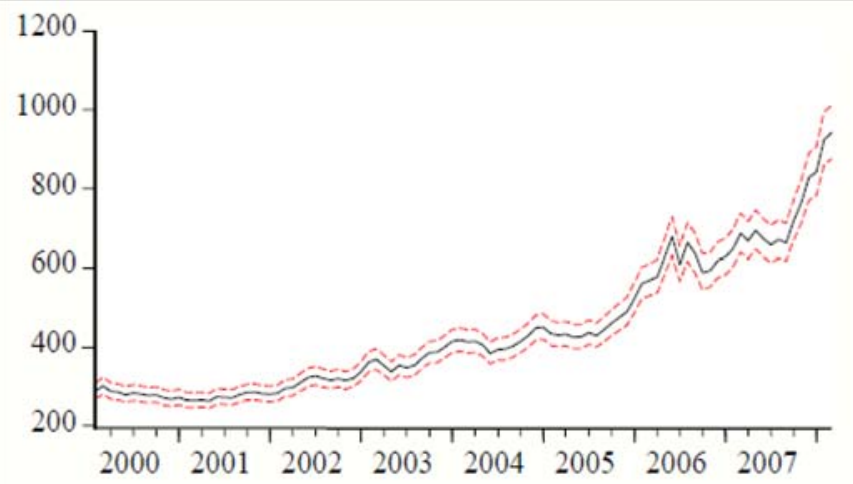

Figure 3: Static (short-term) forecast of gold-U.S. dollar exchange rate

and error. depreciation s how s no difference whether or not actual values are inserted for out of $\mathrm{s}$ a m p le observations. The dynamic forecast (not shown) also results in a s hor t - t e r m depreciation of the dollar but is prone to a higher margin of bias

\section{Conclusion and policy implications}

The empirical results give credence to the argument that the currencies of nations at war come under pressure during times of war. In the case of the United States this has been the case since the Korean War when the United States lost a significant amount of its gold reserves. The continued loss of reserves as a result of the Vietnam War led to destabilizing speculation, suspension of convertibility, and depreciation of the dollar.

The cost of war has historically been miscalculated not only in terms of treasure, but also in terms of strategy and contingent economic shocks like inflation, oil prices, or mortgage crises. Vietnam and Iraq support the notion that the costs of war are inestimable and unpredictable when enemies choose guerilla warfare as their preferred strategy of warfare. When economic shocks conflate with war-time expenditure, geopolitical anxiety, and competition from optimum currency

All the major wars of the twentieth and twenty-first centuries have been accompanied by recessions, and at times stagflation. These, and bloated budget deficits, cause long-term economic disruptions that encourage the search for alternative forms of money and call into question the continued dominance of the dollar. and 1980s.

War-time animosity against the United States and anxiety over the value of the dollar encourages nations to consider dislodging the dollar from its position of preeminence, as evidenced for example by Russia and Iran in 2007: Russia's attempt to replace the dollar for rubles in its financial markets, and Iran trying to persuade OPEC to accept euros rather than dollars for oil to undo the arrangements of the 1970s and 1980s. The Asian Clearing Union, headquartered in Tehran, is also considering the inclusion of the euro to compete with the dollar at a time of weakness. There is no evidence that these measures can be successful in the short-run, but they challenge the once dominant position of the dollar and portend long-run destabilization associated with protracted war.

All the major wars of the twentieth and twenty-first centuries have been accompanied by recessions, and at times stagflation. These, and bloated budget deficits, cause long-term economic disruptions that encourage the search for alternative forms of money and call into question the continued dominance of the dollar. War as an instrument of foreign policy endangers the vitality of the dollar, and its continued dominance under such conditions is highly precarious.

Notes

Christopher E.S. Warburton is Assistant Professor of Economics at the John Jay College of Criminal Justice, New York, U.S.A. He may be reached at Cwarburton@jjay.cuny.edu.

\section{Krueger (1983).}

2. Meese and Rogoff (1983, pp. 3-24).

3. Krugman (1993).

4. Bacchetta and Wincoop (2006).

\section{Mark (1995).}

\section{Johnston and Sun (1997).}

7. They examine in-sample fit, but emphasize the importance of the monetary policy rule and its effects on expectations in determining exchange rates. They then present evidence that exchange rates incorporate news about future macroeconomic fundamentals and demonstrate that the models might well be able to account for observed exchange-rate volatility. See Engel, Mark, and West (2007). geopolitical alliances of the
8. Engel and West (2005, pp. 485-517). 
(C) www.epsjournal.org.uk - Vol. 4, No. 1 (2009)

9. Johnston and DiNardo (1997, pp. 204-206). ARMA models, unlike single equation or simultaneous equation models, analyze the probabilistic properties of economic time series. In this case the dollar value of gold is explained in terms of its past values and shocks. See Gujarati (2003).

10. Mishkin (1992); Obstfeld (1994); Dornbusch, Goldfajn, and Valdes (1995); Sachs, Tornell, and Velasco (1995); Eichengreen, Rose, and Wyplosz (1995); Frankel and Rose (1996); Krugman (1998); Cooper (1999); Salvatore (1999).

11. Optimum currency areas allude to monetary integration of nations and the use of a single currency against others, for example the euro. With permanently fixed exchange rates, an optimum currency area is likely to generate price stability, unlike with flexible rates among the member nations. Greater price stability is attributable to the cancellation or minimization of random shocks within the economies of member states, which make the currency a relatively reliable store of value. See Salvatore (2006).

\section{Mundell (1961).}

13. Mundell (1998).

\section{Ricci (2007); Mongelli (2008).}

15. A country is fully dollarized when it abandons its local currency as an official policy to adopt a much more stable international currency. The concept was originally explained in terms of the adoption of the U.S. dollar. Today, it is loosely applied to the adoption of other international currencies. De facto dollarization occurs when residents of a nation prefer to hold international currencies in order to conduct domestic and international business, although the local government has not repudiated the local currency.

16. Smith (2005, pp. 66-71).

17. Salvatore (2001).

18. Spiro (1999); Essayad and Marx (2001).

19. Mussa (1981).

20. Stiglitz and Bilmes (2008, p. 240).

21. Salvatore (2001, p. 755).
22. Stiglitz and Bilmes (2008, p. 240).

23. Dudley and Passell (1968, p. 437).

24. Daniels and Vanhoose (2005, p.81).

25. Stiglitz and Bilmes (2008, p.236).

26. Stiglitz and Bilmes (2008, p. 33).

27. Stationarity says that the mean and variance of the series are constant through time; the mean and variance of intervening periods will be identical. This facilitates the projection of the series in the short-run.

28. Autocorrelation is the correlation between members of a time series. The sample autocorrelation is the ratio of the sample covariance $(\gamma \mathrm{k})$ to sample variance $(\gamma)$ and the sample autocorrelation function at a particular lag $(\rho)$ is $(\gamma \mathrm{k}) /(\gamma)$. The value of the autocorrelation function always lies between -1 and +1 and the correlogram is the visual (graphical) representation of the autocorrelation and partial autocorrelation functions. The partial autocorrelation is the correlation between two lags at different periods when intervening lags are not considered; that is the amount of correlation between a variable and its lag that is not explained by correlations at all lower-order lags. For a time series to be considered stationary, its autocorrelations at various lags must hover around zero and the null hypothesis that the autocorrelation values are not jointly zero must be rejected. The Q-statistic, developed by Box and Pierce, is the test statistic used here. It tests for a pure random or white noise process.

29. An infinite MA model is invertible if for $\mathrm{A}(\mathrm{L})=1-\alpha_{1} \mathrm{~L}-\alpha_{2} \mathrm{~L}^{2} \ldots \alpha_{\mathrm{p}} \mathrm{L}^{\mathrm{p}}$ a solution of the form $1 /\left(1-\alpha_{1} L\right)+1 /\left(1-\alpha_{2} L^{2}\right) \ldots+1 /\left(1-\alpha_{p} L^{p}\right)$ can be obtained; where $L$ is a lag operator indicating the number of lags and $\alpha$ is a parameter to be estimated and presumed to be less than 1 .

\section{References}

Bacchetta, P. and E. Wincoop. 2006. "Can Information Heterogeneity Explain the Exchange Rate Determination Puzzle?” American Economic Review, Vol. 96, pp. 552-576.

Cooper, R. 1999. “The Asian Crisis: Causes and Consequences,” pp.17-28 in A. Harwood, R. Litan, and M. Pomerleano, eds. Financial Markets and Development: The Crisis in Emerging Markets. Washington, DC: Brookings Institution Press.

Daniels, J.P. and D.D. Vanhoose. 2005. International Monetary and Financial 
Economics. Mason, OH: Thomson South-Western.

Dornbusch, R., I. Goldfajn, and R.O. Valdes. 1995. "Currency Crises and Collapses.” Brookings Papers on Economic Activity, Vol. 2, pp. 219-270.

Dudley, L. and P. Passell. 1968. "The War in Vietnam and the United States Balance of Payments.” The Review of Economics and Statistics, Vol. 50, No. 4, pp. 437-442.

Eichengreen, B., A. Rose, and C. Wyplosz. 1995. "Exchange Market Mayhem: The Antecedents and Aftermath of Speculative Attacks.” Economic Policy, Vol. 21, pp. 249-312.

Engel, C. and K.D. West. 2004. “Accounting for Exchange Rate Variability in Present Value Models when the Discount Factor is Near One.” NBER Working Paper No. 10267. Cambridge, MA: National Bureau of Economic Research.

Engel, C. and K.D. West. 2005. “Exchange Rates and Fundamentals.” Journal of Political Economy, Vol. 113, pp. 485-517.

Engel, C., N. Mark, and K.D. West. 2007. "Exchange Rate Models Are Not as Bad as You Think.” NBER Working Paper No. 13318. Cambridge, MA: National Bureau of Economic Research.

Essayad, M. and D. Marx. 2001. “OPEC and Optimal Currency Portfolios.” Oil, Gas, and Energy Quarterly, Vol. 49, No. 2, pp. 363-384.

Frankel, J.A. and A.K. Rose. 1996. "Currency Crashes in Emerging Markets: An Empirical Treatment.” Journal of International Economics, Vol. 41, pp. 351-366.

Gujarati, D. 2003. Basic Econometrics. New York: McGraw-Hill.

Johnston, B. and Y. Sun. 1997. “Some Evidence on Exchange Rate Determination.” IMF Working Paper No. 97/98. Washington, DC: International Monetary Fund [accessed 21 April 2008].

Johnston, J. and J. DiNardo. 1997. Econometric Methods. New York: McGraw-Hill.

Krueger, A. 1983. Exchange Rate Determination. Cambridge, MA: Cambridge University Press.

Krugman, P. 1993. "Recent Thinking About Exchange Rate Determination and Policy.” RBA Annual Conference Volume No. Acv1993-02 [Australia]. http://www.rba.gov.au/

Krugman, P. 1998. “What happened to Asia?” Mimeo. Cambridge, MA: Massachusetts Institute of Technology.

Mark, N.C. 1995. "Exchange Rates and Fundamentals: Evidence on Long-Horizon Predictability.” American Economic Review, No. 85, pp. 201-218.

Meese, R.A. and K.S. Rogoff. 1983. "Empirical Exchange Rate Models of the Seventies: Do They Fit Out of Sample?” Journal of International Economics. Vol. 14, pp. 3-24.

Mishkin, F. 1992. “Anatomy of a Financial Crisis.” Journal of Evolutionary Economics, Vol. 2, pp. 115-130.

Mongelli, F.P. 2008. "European Economic and Monetary Integration and the Optimum Currency Area Theory.” Economic Papers 302. Brussels, Belgium:
European Commission.

Mundell, R.A. 1961. “A Theory of Optimum Currency Areas.” American Economic Review, No. 51, pp. 509-517.

Mussa, M. 1981. "Sticky Individual Prices and the Dynamics of the General Price Level.” Carnegie-Rochester Conference on Public Policy, Vol. 15, pp. 261-296.

Obstfeld, M. 1994. “The Logic of Currency Crises.” Cahiers Economiques et Monetaires, Vol. 43, pp. 189-213.

Pindyck, R.S. and D.L. Rubinfeld. 1998. Econometric Models and Econometric Forecasts. New York: McGraw-Hill.

Ricci, L.A. 2008. “A Model of an Optimum Currency Area. Economics, Vol. 2, No. 2008-8, pp. 1-31.

Sachs, J., A. Tornell, and A.Velasco. 1996. "Financial Crises in Emerging Markets: the Lessons from 1995.” Brookings Papers on Economic Activity, Vol. 1, pp. 147-215.

Salvatore, D. 2001. International Economics. New York: Wiley.

Salvatore, D. 1999. "Lessons from the Financial Crisis in East Asia." Journal of Policy Modeling, Vol. 21, No. 3, pp. 283-287.

Spiro, D.E. 1999. The Hidden Hand of American Hegemony: Petrodollar Recycling and International Markets. Ithaca: Cornell University Press.

Stiglitz, J.E. and L.J. Bilmes. 2008. The Three Trillion Dollar War: The True Cost of The Iraq Conflict. New York: Norton. 